Volume II, No.2 Desember 2012/1433 H

\title{
HEALTH AND SAFETY DISCLOSURES IN INDONESIA: A CSR CONVERGENCE STRATEGY
}

\author{
Fitra Roman Cahaya \\ (Dosen Prodi Akuntansi Fakultas Ekonomi Universitas Islam Indonesia)
}

\begin{abstract}
Abstrak
Studi ini menguji faktor-faktor yang mempengaruhi pengungkapan sukarela informasi mengenai kesehatan dan keselamatan kerja (OHSPD). Pedoman pelaporan dari Global Reporting Initiative (GRI) digunakan sebagai standar pengukuran pengungkapan. Analisis statistik deskriptif menunjukka bahwa hanya sekitar $29 \%$ perusahaan publik di Indonesia secara sukarela menyediakan OHSPD. Analisis regresi logistik menunjukkan bahwa pengungkapan informasi seperti ini secara positif dipengaruhi oleh tipe industri dan operasi internasional. Tampaknya, perusahaan di Indonesia secara mimetic menyediakan program kesehatan dan keselamatan untuk pekerjanya dan mengkomunikasikan program tersebut di dalam laporan tahunannya sehingga pilihan mereka terhadap aktivitas Corporate Social Responsibility (CSR) ini dapat disatukan dengan aktivitas CSR yang pada umumnya dilakukan oleh saingan mereka di dalam industri spesifik mereka dan di luar negeri.
\end{abstract}

Kata kunci: Pengungakapan kesehatan dan keselamatan kerja, Teori institusional Global Reporting Initiative, Corporate social responsibility

\section{INTRODUCTION}

This paper examines the key determinants of voluntary Occupational Health and Safety Program Disclosures (OHSPD) in Indonesia Stock Exchange (IDX) listed companies' annual reports. OHSPD represents information concerning companies' education, training, counseling, prevention, and risk-control programs in place to assist workforce members, their families, or community members regarding serious diseases (Global Reporting Initiative, 2006). Under Act no. 13/2003, companies are required to protect their workers' health and safety (Pemerintah Republik Indonesia, 2003). Health and safety program is definitely one of the main ways for companies to respond to that requirement. Such143 a program is then communicated to stakeholders through OHSPD in annual reports.

The number of accidents during work in Indonesia is very high. In

JURNAL EKONOMI

SYARIAH

IND143ONESIA
2011, for instance, 99,491 known work accidents occurred (Chevny, 2012). This number equals to about 414 cases per day (Chevny, 2012). Sadly, such a number always increased, particularly in the last five years, showing that the commitment of Indonesian companies to deal with health and safety 143injuries or even deaths (Markkanen, 2004). These mostly occur in high profile industries such as mining. Given the high number of work 
accidents, it is considered critical to investigate OHSPD practices and the determinants of those practices in Indonesia.

Although there is a regulation requiring companies to deal with health and safety issues, the accounting-related regulations in Indonesia look silent on such issues. Act No. 40/2007 (requirements for all companies to provide annual reports and financial statements in accordance with the Indonesian accounting standard (PSAK) as well as requirements for limited liability companies to provide information regarding their corporate social responsibility (CSR) performance and PSAK, for example, do not require companies to provide OHSPD (IAI, 2007; Pemerintah Republik Indonesia, 2007; Waagstein, 2011).

This study contributes to the literature in a number of ways. Firstly, it provides insights into the disclosure practices of occupational health and safety program, a vital subset of labour-related CSR reporting which is still under-researched. Secondly, it empirically investigates the key determinants of OHSPD. Such an investigation is rarely examined in prior literature. Finally, this study uses the Global Reporting Initiative (GRI) as the disclosure benchmark. It is argued that the use of GRI best represents CSR issues in all parts of the world, including labour-related CSR issues in Indonesia (Crane et al., 2008; Cahaya et al., 2012; Global Reporting Initiative, 2010).Banyak faktor yang dapat mempengaruhi perkembangan usaha asuransi di suatu negara, baik faktor lingkungan eksternal maupun lingkungan internal.

\section{THEORETICAL FRAMEWORK AND HYPOTHESES DEVELOPMENT}

This paper adopts isomorphic institutional theory as the underlying theoretical framework. Institutional theory views disclosures as a tool to respond to institutional pressures (see Deegan, 2009; Cahaya et al., 2012). There are three sources of isomorphic institutional pressures. Firstly, the pressures can come from influential stakeholders such as companies' creditors, which is termed as coercive pressure (DiMaggio and Powell, 1983). Secondly, the pressures can exist within a competitive business environment therefore companies in that environment undertake similar practices in order to survive, which is known as mimetic pressure (DiMaggio and Powell, 1983). Thirdly, pressures can come from groups of norms (e.g. managers) to undertake particular practices such as performing good CSR practices and communicating these practices in their annual reports, which is termed as normative pressure (DiMaggio and Powell, 1983).

In Indonesia, there are two main corporations' stakeholder groups which are very influential. These groups are creditors and the government (see Cahaya et al. 2008; Cahaya et al., 2012). This is because Indonesian companies rely extensively on creditors' funds and must undertake particular practices in line with the government's regulations (Cahaya et al. 2008; Cahaya et al., 2012). Coercive pressures from creditors and the government thus potentially present. Consistent with prior studies which found the significant impacts of leverage and government ownership (e.g. Firer and Williams, 2005; Deumes and Knechel, 2008), two coercive-based hypotheses are proposed:

Fitra

Roman C 
H1: There is a positive association between leverage and the propensity to communicate occupational health and safety programs in the annual reports of IDX listed companies

H2: There is a positive association between government ownership and the propensity to communicate occupational health and safety programs in the annual reports of IDX listed companies

Under the umbrella of institutional theory, companies within a similar industry tend to model themselves to the industry norms, especially if they see that other companies in that similar industry gain more successful results due to the adoption of a particular practice (Amran and Devi, 2007). The similarity in reporting practices within a particular industry is less likely to be reflected across fundamentally different industry groupings. For example, companies ${ }^{1}$ in high profile industries such as mining companies potentially disclose more information on safety program as their workers have a greater risk of injury during operations than workers in low profile industries (such as services).

Similarly, a company which also operates overseas potentially imitates their successful competitors' practices to best survive in a global arena. The possible impacts of industry type and international operations on companies' practices potentially extend to disclosure practices (Cahaya et al., 2012). In line with the above arguments and the results of past studies (e.g. Hackston and Milne, 1996; Zarzeski, 1996; Nurhayati et al., 2006), two mimetic-based hypotheses are predicted:

H3: There is a positive association between high profile IDX listed companies and the propensity to communicate occupational health and safety programs in the annual reports

H4: There is a positive association between the presence of international operations and the propensity to communicate occupational health and safety programs in the annual reports of IDX listed companies Amran and Devi (2007) argue that normative isomorphism pressures on companies to communicate CSR-related information are potentially present when a company has an explicit and clearly stated goal related to CSR matters. This is because the managers of those companies normally attempt to achieve that goal and disclose such a goal achievement or any related performances in their annual reports. Such an argument is applicable to the context of OHSPD. Normative isomorphism also potentially presents when there is pressure from independent commissioners given that their position is less aligned to the management (Eng and Mak, 2003). Thus, in the context of this study, it is arguable that companies with a greater composition of independent commissioners on the board tend to

$\begin{array}{cl}\text { Health } & 1 \text { Roberts (1992, p. 65) originally defines high profile industries as those "with consumer visibility, a } \\ \text { And } & \begin{array}{l}\text { high level of political risk, and concentrated, intense competition". For the purpose of this paper, and } \\ \text { in line with Cahaya et al. (2012), the definition of high profile industries is made more specific with } \\ \text { an emphasis on those having a high level of health and safety risk to workers such as work-related } \\ \text { accidents. The classification of IDX listed companies within high and low profile industries is } \\ \text { explained in Table 1. }\end{array}\end{array}$ JURNAL EKONOMI SYARIAH INDONESIA, Volume II, No.2 Desember 2012 
communicate information regarding occupational health and safety programs.

Another potential normative pressure can come from a foreign parent company. It is noted in the literature that the presence of a foreign parent company influences disclosure practices (see Craig and Diga, 1998). This is because a subsidiary and its foreign parent company potentially have differences in their reporting environments (Monteiro and AibarGuzmán, 2009). The differences may include different national reporting regulations, legitimacy issues, managerial policies, etc. According to Monteiro and Aibar-Guzmán (2009), a subsidiary is usually pressed by its foreign parent company to undertake reporting practices in accordance with the reporting environment within the parent company's country.

The impacts of goal factor, independence of board, and foreign company ownership on disclosure practices are well documented in prior studies (e.g. White et al., 2007). Three normative-based hypotheses are thus tested:

H5: There is a positive association between an explicit and clearly stated goal factor related to the sustainable value of employees and the propensity to communicate occupational health and safety programs in the annual reports of IDX listed companies

H6: There is a positive association between the proportion of independent commissioners and the propensity to communicate occupational health and safety programs in the annual reports of IDX listed companies

H7: There is a positive association between the presence of a foreign parent company and the propensity to communicate occupational health and safety programs in the annual reports of IDX listed companies

Past studies suggest that there are other variables that should be controlled as they potentially intervene in the relationships between the independent and dependent variables in CSR reporting studies (Williams, 1999; Haniffa and Cooke, 2005). These variables are company size, economic performance and age of business. More mature companies, for example, potentially disclose more social information as their history of involvement in CSR are entrenched (Roberts, 1992). It is thus expected that the inclusion of these three variables as the control variables in this paper helps in explaining the propensity to provide OHSPD.

\section{RESEARCH METHODOLOGY}

A sample of 223 publicly listed companies is selected from a population of 383 companies from the Indonesia Stock Exchange (IDX) for the financial year ending 2007 (IDX, 2008). The sample selection is based on the accessibility of those companies' annual reports from the internet and the clarity of the reports' presentation in the Adobe Reader file.

Consistent with previous CSR-related disclosure studies in Indonesia (e.g. Cahaya et al., 2012), this paper employs the GRI Occupational Health and Safety Program indicator as the disclosure benchmark. In particular, in relation to labour disclosure, GRI labourrelated guidelines have been developed based on internationally

Fitra

Roman C

146 
recognized standards including ILO's standards (Global Reporting Initiative, 2006).

The dependent variable in this study, OHSPD, is measured by a dichotomous scale, coded as 1 (one) if a company discloses any information regarding companies' education, training, counseling, prevention, and riskcontrol programs in place to assist workforce members, their families, or community members regarding serious diseases (Global Reporting Initiative, 2006) or 0 (zero) if otherwise.

Table 1 shows the measurement techniques for the independent and control variables examined in this paper. The possible effects of these variables on OHSPD are tested by logistic regression.

Table 1: Measurement technique of the independent and control variables

\begin{tabular}{|c|c|c|c|c|}
\hline $\begin{array}{c}\text { Isomorphic } \\
\text { process }\end{array}$ & $\begin{array}{c}\text { Independent } \\
\text { variables }\end{array}$ & $\begin{array}{l}\text { Control } \\
\text { variables }\end{array}$ & Measurement & $\begin{array}{c}\text { Type of } \\
\text { data }\end{array}$ \\
\hline \multirow[t]{2}{*}{$\begin{array}{l}\text { Coercive } \\
\text { isomorphism }\end{array}$} & Leverage & & $\begin{array}{l}\text { Total liabilities divided by total } \\
\text { assets }\end{array}$ & Continuous \\
\hline & $\begin{array}{l}\text { Government } \\
\text { ownership }\end{array}$ & & $\begin{array}{l}1=\text { there is a proportion of } \\
\text { government } \\
\text { ownership } \\
0=\text { otherwise }\end{array}$ & Categorical \\
\hline \multirow[t]{2}{*}{$\begin{array}{l}\text { Mimetic } \\
\text { isomorphism }\end{array}$} & Industry type ${ }^{a}$ & & $\begin{array}{l}1=\text { high profile industry } \\
0=\text { low profile industry }\end{array}$ & Categorical \\
\hline & $\begin{array}{l}\text { International } \\
\text { operations }\end{array}$ & & $\begin{array}{l}1 \text { =Yes-Have material foreign } \\
\text { sales or a } \\
\text { foreign subsidiary or a foreign } \\
\text { branch } \\
\text { office } \\
0=\text { No material foreign sales, } \\
\text { foreign } \\
\text { subsidiaries or foreign branch } \\
\text { offices }\end{array}$ & Categorical \\
\hline \multirow[t]{6}{*}{$\begin{array}{l}\text { Normative } \\
\text { isomorphism }\end{array}$} & $\begin{array}{l}\text { Explicit and } \\
\text { clearly stated } \\
\text { goal related to } \\
\text { the sustainable } \\
\text { value of } \\
\text { employees }\end{array}$ & & $\begin{array}{l}1=\text { the company has clearly } \\
\text { communicated goals } / \text { missions } \\
\text { related to sustainable value of } \\
\text { its } \\
\text { employees } \\
0=\text { otherwise }\end{array}$ & Categorical \\
\hline & $\begin{array}{l}\text { Independence of } \\
\text { board }\end{array}$ & & $\begin{array}{l}\text { Percentage of independent } \\
\text { commissioners in the board }\end{array}$ & Continuous \\
\hline & $\begin{array}{l}\text { Foreign company } \\
\text { ownership }\end{array}$ & & $\begin{array}{l}1=\text { the company is a subsidiary of } \\
\text { a } \\
\text { foreign company } \\
0=\text { otherwise }\end{array}$ & Categorical \\
\hline & & $\begin{array}{l}\text { Company } \\
\text { size }\end{array}$ & Log of total assets & Continuous \\
\hline & & $\begin{array}{l}\text { Economic } \\
\text { performance }\end{array}$ & $\begin{array}{l}\text { Return on Assets (ROA) : } 2 \text { year } \\
\text { average }\end{array}$ & Continuous \\
\hline & & $\begin{array}{l}\text { Age of } \\
\text { business }\end{array}$ & Number of years from inception & Continuous \\
\hline
\end{tabular}


aConsistent with Nurhayati (2005), IDX's official industry classification, which consists of nine industries, is reclassified into the high-low coding. Seven industries namely agriculture, mining, basic industry and chemicals, miscellaneous industry, consumer goods industry, property and real estate, and infrastructure, utilities and transportation are classified as high profile industries while the other two, finance and trade, services and investment, are classified as low profile industries.

\section{RESULTS}

The statistical results show that there are 65 sample companies, which is about $29 \%$ of total sample companies, which voluntarily communicate health and safety programs in their annual reports. This percentage is considered low given that the number of work accidents in Indonesia is extremely high. This implies that companies in Indonesia do not care about their workers' safety. Table 2 summarizes the results of logistic regression ${ }^{2}$, highlighting the outcomes of the hypotheses testing of this study.

Table 2: Results of logistic regression

\begin{tabular}{lccc}
\hline \multicolumn{1}{c}{ Variable } & $\begin{array}{c}\text { Predicted } \\
\text { sign }\end{array}$ & Coefficient & $P$-value \\
\hline Leverage & + & +0.702 & 0.266 \\
Government ownership & + & +0.017 & 0.979 \\
Industry type & + & +1.219 & $0.001^{* * *}$ \\
International operations & + & +1.742 & $0.000^{* * *}$ \\
Explicit and clearly stated goal & + & +0.109 & 0.762 \\
related to the sustainable value of & & & \\
employees & & & \\
Independence of board & + & -3.326 & $0.041^{* *}$ \\
Foreign company ownership & + & +0.206 & 0.678 \\
Company size (control variable) & + & -0.027 & 0.805 \\
Economic performance (control & + & +6.377 & $0.018^{* *}$ \\
variable) & & & \\
Age of business (control variable) & + & -0.005 & 0.619 \\
\hline
\end{tabular}

Source: Original table

*** significant at $1 \%$ level; ${ }^{* *}$ significant at $5 \%$ level; * significant at $10 \%$ level.

It is shown in Table 2 that industry type, international operations, independence of board, and economic performance significantly affect the propensity of IDX listed companies to disclose information about education, training, counseling, prevention, and risk-control programs in place to assist workforce members, their families, or community members regarding serious diseases (with $p$-values of $0.001,0.000,0.041$, and 0.018 respectively). The coefficients of industry type (Hypothesis 3), international operations (Hypothesis 4 ), and economic performance (control variable) are positive $(+1.219,+1.742$, and +6.377 respectively). These indicate that high

\footnotetext{
${ }^{2}$ According to Hair et al. (1998) logistic regression does not face strict assumptions such as normality like other multivariate analyses. Accordingly, logistic regression is considered as a robust statistical tool which can be appropriately used in many situations (Hair et al., 1998). Thus, this paper does not perform any assumption tests regarding the logistical regression analysis.
}

Fitra

Roman C

148 
profile companies, compan ies operating internationally, and companies with better economic performance tend to voluntarily provide OHSPD.

In contrast with the above three significant variables, the coefficient of independence of board is negative (-3.326). This suggests that companies with a greater proportion of independent commissioners in the board tend not to provide OHSPD in their annual reports. As this finding is not consistent with Hypothesis 6, only Hypotheses 3 and 4 are accepted. The logistic regression results therefore suggest that, in Indonesia, OHSPD practices are explained by the specific mimetic variant of isomorphic institutional theory.

\section{DISCUSSION}

The results show that very few companies (only about $29 \%$ of IDX listed companies) voluntarily communicate information regarding companies' education, training, counseling, prevention, and risk-control programs in place to assist workforce members, their families, or community members regarding serious diseases. This very low level of disclosure is consistent with previous studies (e.g. Nurhayati et al., 2006; Cahaya et al., 2006) suggesting that the level of CSR-related disclosures in Indonesia is low.

An important finding of the hypotheses testing of this study is the positively significant influence of mimetic-based explanatory variables, which are industry type and international operations. High profile companies whose employees generally have a greater injury risk tend to mimetically model themselves by disclosing information about occupational health and safety programs. There is therefore uniformity of occupational health and safety program communication within industry groupings. This finding is consistent with Roberts (1992) and Nurhayati et al. (2006) past conclusions.

One explanation for this result is that the mimetic practices by IDX listed companies within a high or low profile industry grouping exist mainly due to the similar risks within each industry type. Arguably, the risk that mostly threatens workers in high profile industries such as mining is work-related accidents. This argument is supported by the high number of work accidents in Indonesia (65,000 known cases during the 2007 financial year alone, and the number even increased to 99,491 in 2011)(Damayanti, 2008; Chevny, 2012). More than 60\% of Indonesian workers are employed within high profile industries (BPS, 2010). Thus, it is arguable that the most urgent labour issue that must be first addressed and reported by high profile companies is occupational health and safety programs.

The high profile companies' focus on occupational health and safety programs may further indicate that those companies are also mimetically pressed to show the annual report readers that they seriously 'guarantee'

Health their workers' productivity without any major work-related accidents. In And other words, through OHSPD, high profile companies probably want to highlight that occupational health and safety is not a barrier or a threat to 149 their survival.

JURNAL EKONOMI SYARIAH INDONESIA, Volume II, No.2 Desember 2012 
In regards to international operations, it appears that Indonesian companies with international operations copy the OHSPD practices of their competitors overseas so that they can better survive in a global arena (Cahaya et al., 2012). The positively significant influence of international operations is consistent with previous CSR reporting studies such as Zarzeski (1996).

One explanation for this positively significant relationship is that Indonesian companies' overseas competitors are more socially responsible to their workers, particularly in the context of occupational health and safety programs, and disclose information regarding this responsibility in their annual reports. The CSR activities may include the application of SA $8000^{3}$ by companies in countries such as China and Japan (SA8000, standar manajemen baru, 2006). In line with the mimetic tenet of institutional theory, to compete with such foreign competitors, Indonesian companies then copy their labour reporting practices.

One key implication of the above results is that Indonesian companies' occupational health and safety related CSR programs are strived to be converged in line with the health and safety related CSR programs generally undertaken by their competitors within their specific industry grouping (e.g. within high profile industry) and by their competitors overseas. Such a convergence appears to be a critical mimetic strategy given that the competition within a similar industry and the competition within a global arena are very tight these days.

The environment of CSR activities and reporting practices in Indonesia itself is still uncertain as the CSR-related regulations remain unclear (Cahaya et al., 2012). The concept of CSR is also relatively new and may not be fully and well grasped by companies not only in this developing nation but also around the world (Misani, 2010; Cahaya et al., 2012). This situation forces companies to converge with a set of socially accepted behaviour usually undertaken by their rivals such as providing good health and safety programs for workers and communicating these programs in the annual reports (see Misani, 2010). Misani (2010) states that such a convergence strategy is needed for ensuring companies' legitimacy within a complex social business practice.

In addition to the socially accepted behaviour that companies can converge with, they can also adopt a defined set of practices or guidelines such as the GRI guidelines as parts of their converge strategy (Misani, 2010). Misani (2010) argues that the convergence by companies with the socially acceptable 'standards' as well as with the defined set of formal guidelines represents the effectiveness of mimetism of companies' practices. This is because companies do observe, consider, accept, and voluntarily undertake certain practices, which is OHSPD in the context of this paper, in accordance with the practices done by the majority of organizations within the same institutional environment (e.g. within a high profile industry

\footnotetext{
3 SA8000 is a management standard recently applied by companies, particularly in developed nations. This standard focuses on companies' social accountability to their workers based on international norms such as International Labor Organization (ILO) conventions (SA8000, standar manajemen baru, 2006; Fuentes-García et al., 2008).
}

Fitra

Roman C 
grouping). Such a convergence is empirically evidenced by the significant findings of mimetic variables in this paper.

In summary, the propensity to disclose information about occupational health and safety programs in Indonesia is explained by the specific mimetic variant of isomorphic institutional theory. This finding documents the positively significant influence of industry type and international operations. This finding also highlights that the mimetism of Indonesian companies' OHSPD practices is considered effective given that they converge with the health and safety related CSR practices undertaken by the majority of their rivals within the same industry grouping as well with the same country of business operation.

As with all research, this study has limitations. Firstly, this paper does not use separate stand-alone reports such as sustainability reports as the source of disclosure data. This is because such a medium is not uniformly used by most companies in developing countries, particularly in Indonesia (Baker and Naser, 2000; Chambers et al., 2003, Cahaya et al., 2011a). An annual report itself is an official form of communication that must be provided by listed companies in Indonesia (Badan Pengawas Pasar Modal dan Lembaga Keuangan, 2008). Secondly, only two influential stakeholder groups namely creditors and the government are examined in this paper. In fact, other influential stakeholder groups such as the general public and political groups are also potentially be able to give pressures to companies to communicate occupational health and safety information (see Cahaya et al., 2006; Gunawan, 2009; Cahaya et al., 2011b). Future research examining the potential pressure of those stakeholder groups could therefore be undertaken to provide more insights into the OHSPD practices in this emerging nation.

Health

And 


\section{REFERENCES}

Amran, A. and SS. Devi. 2007. Corporate Social Reporting in Malaysia: a Mixed Method Approach. Paper presented at the Fifth Asia Pacific Interdisciplinary Research in Accounting Conference. Auckland.

Badan Pengawas Pasar Modal dan Lembaga Keuangan. 2008. http:// bapepam.go.id. Accessed 25 July 2008.

BPS. 2010. http://www.bps.go.id/. Accessed 23 February 2010.

Baker, A. and K. Naser. 2000. Empirical Evidence on Corporate Social Disclosure (CSD) Practices in Jordan. International Journal of Commerce \& Management. 10 (3/4). 18-34.

Cahaya, FR., SA. Porter and AM. Brown. 2006. Nothing to Report? Motivations for Non-disclosure of Social Issues by Indonesian Listed Companies. The Journal of Contemporary Issues in Business and Government. 12 (1). 43-61.

Cahaya, FR., SA. Porter and AM. Brown. 2008. Social Disclosure Practices by Jakarta Stock Exchange Listed Entities. Journal of the Asia-Pacific Centre for Environmental Accountability. 14 (1). 2-11.

Cahaya, FR., SA. Porter, G. Tower and A. Brown. 2011a. Communication of Labour Disclosure in the Media: an Examination of Coercive Pressure in Indonesia. Paper presented at the Thirty Fourth Annual Congress of the European Accounting Association. Rome.

Cahaya, FR., SA. Porter, G. Tower and A. Brown. 2011b. Isomorphic Propensities to Communicate Occupational Health and Safety Issues. Paper presented at the British Accounting and Finance Association Conference. Birmingham.

Cahaya, FR., SA. Porter, G. Tower and A. Brown. 2012. Indonesia's Low Concern for Labour Issues. Social Responsibility Journal. 8 (1). 114132.

Chambers, E., W. Chapple, J. Moon and M. Sullivan. 2003. CSR in Asia: a Seven Country Study of CSR Website Reporting. http:// www.nottingham.ac.uk/business/ICCSR/pdf/ResearchPdf s/09-2003.PDF. Accessed 16 April 2008.

Chevny, AA. 2012. Keselamatan Tenaga Kerja: Jamsostek Intensifkan Pelatihan K3. http://www.bisnis.com/articles/keselamatan-tenaga-kerjajamsostek-intensifkan-pelatihan-k3. Accessed 6 June 2012.

Craig, R. and J. Diga. 1998. Corporate Accounting Disclosure in ASEAN. Journal of International Financial Management \& Accounting. 9 (3). 246274.

Crane, A., D. Matten and LJ. Spence. 2008. Corporate Social Responsibility: Readings and Cases in A Global Context. London. Routledge.

Damayanti, N. 2008. Presiden Minta Angka Kecelakaan Kerja Diturunkan. http:// www.tempointeraktif.com/hg/nasional/2008/06/25/brk,2 0080625-126626,id.html. Accessed 25 October 2009.

Fitra

Deegan, C. 2009. Financial Accounting Theory. $3^{\text {rd }}$ ed. Sydney: McGraw-Hill.

Deumes, R. and W. Knechel. 2008. Economic Incentives for Voluntary Reporting on Internal Risk Management and Control Systems. Auditing: A Journal of Practice and Theory. 27 (1). 35-66.

Roman C

152 
DiMaggio, PJ. and WW. Powell. 1983. The Iron Cage Revisited: Institutional Isomorphism and Collective Rationality in Organizational Fields. American Sociology Review. 48 (2). 146 - 160.

Eng, LL. and YT. Mak. 2003. Corporate Governance and Voluntary Disclosure. Journal of Accounting and Public Policy. 22 (4). 325-345.

Firer, S. and SM. Williams. 2005. Firm Ownership Structure and Intellectual Capital Disclosures. South African Journal of Accounting Research. 19 (1). 1-18.

Fuentes-García, FJ., JM. Núñez-Tabales and R. Veroz-Herradón. 2008. Applicability of Corporate Social Responsibility to Human Resources Management: Perspective from Spain. Journal of Business Ethics. 82 (1). 27-44.

Global Reporting Initiative. 2006. Sustainability Reporting Guidelines. Amsterdam.

GRI.

http://www.globalreporting.org/NR/rdonlyres/ED9E9B36-AB544DE1-BFF2-5F735235CA44/0/G3_GuidelinesENU.pdf. Accessed 23 March 2008.

Global Reporting Initiative. 2010. http://www.globalreporting.org. Accessed 27 December 2010.

Gunawan, J. 2009. Corporate Social Disclosures in Indonesia: Stakeholders' Influence and Motivation. Paper presented at the 8th Australasian Conference on Social and Environmental Accounting Research. Christchurch.

Hackston, D. and MJ. Milne. 1996. Some Determinants of Social and Environmental Disclosures in New Zealand Companies. Accounting, Auditing \& Accountability Journal. 9 (1). 77-108.

Hair, JF., RE. Anderson, RL. Tatham, and WC. Black. 1998. Multivariate Data Analysis. $5^{\text {th }}$ ed. New Jersey. Prentice-Hall.

Haniffa, RM. and TE. Cooke. 2005. The Impact of Culture and Governance on Corporate Social Reporting. Journal of Accounting and Public Policy. 24 (5). 391-430.

IAI. 2007. Standar Akuntansi Keuangan per 1 September 2007. Jakarta. Penerbit Salemba Empat.

IDX. 2008. http://www.idx.co.id/. Accessed 15 March 2008.

Markkanen, PK. 2004. Keselamatan dan Kesehatan Kerja di Indonesia. http://www.ilo.org/public/english/region/asro/manila/downloa ds/wp9.pdf. Accessed 4 November 2009.

Misani, N. 2010. The Convergence of Corporate Social Responsibility Practices. Management Research Review. 33 (7). 734 - 748.

Monteiro, S. and B. Aibar-Guzmán. 2009. Determinants of Environmental Disclosure in the Annual Reports of Large Companies Operating in Portugal. Corporate Social Responsibility and Environmental Management. 17 (4). 185-204.

Health Nurhayati, R. 2005. The Determinants of the Level of Natural And Environmental Disclosures of JSX Listed Entities. Master Thesis, Curtin University of Technology. 
Nurhayati, R., A. Brown and G. Tower. 2006. Understanding the Level of Natural Environmental Disclosures by Indonesian Listed Companies. Journal of the Asia Pacific Centre for Environmental Accountability. 12 (3). 4-11.

Pemerintah Republik Indonesia. 2003. Undang-undang Republik Indonesia Nomor 13 Tahun 2003 tentang Ketenagakerjaan. http://www.nakertrans.go.id/uploads/doc/perundangan/417815 068485219144c77b.pdf. Accessed 26 January 2009.

Pemerintah Republik Indonesia. 2007. Undang-undang Republik Indonesia Nomor 40 tahun 2007 tentang Perseroan Terbatas http://www.djkn.depkeu.go.id/download/Peraturan/UndangUndang/UU40-2007.pdf. Accessed 19 March 2008.

Roberts, RW. 1992. Determinants of Corporate Social Responsibility Disclosure: an Application of Stakeholder Theory. Accounting, Organizations and Society. 17 (6). 595-612.

SA8000, standar manajemen baru. 2006. http://www.portalhr.com/majalah/edisisebelumnya/strategi/1id 341.html. Accessed 8 July 2008.

Waagstein, PR. 2011. The Mandatory Corporate Social Responsibility in Indonesia: Problems and Implications. Journal of Business Ethics. 98 (3). 455-466.

White, G., A. Lee and G. Tower. 2007. Drivers of Voluntary Intellectual Capital Disclosure in Listed Biotechnology Companies. Journal of Intellectual Capital. 8 (3). 517 - 537.

Williams, SM. 1999. Voluntary Environmental and Social Accounting Disclosure Practices in the Asia Pacific Region: an International Empirical Test of Political Economy Theory. The International Journal of Accounting. 34 (2). 209-238.

Zarzeski, MT. 1996. Spontaneous Harmonization Effects of Culture and Market Forces on Accounting Disclosure Practices. Accounting Horizons. 10 (1). 18-37.

Fitra

Roman C 